\title{
Persepsi Siswa Tentang Profesionalisme Guru Ditinjau Dari Kompetensi Pedagogik Terhadap Motivasi Belajar Bahasa Arab
}

\author{
Zera Ilhami \\ Universitas Islam Negeri Sunan Kalijaga Yogyakarta \\ zerailhami97@gmail.com
}

\author{
Article History: \\ Received: \\ 30 November 2020 \\ Revised: \\ 18 Desember 2020 \\ Accepted: \\ 30 Desember 2020
}

\section{Keywords:}

student perception, teacher pedagogical competence, motivation, Arabic

\begin{abstract}
:
This research aims to explain the importance of teacher professionalism in terms of pedagogy owned by an educator. By mastering pedagogical competencies, educators or teachers can achieve learning objectives perfectly. With this challenge, an educator must complete all aspects of learning, methods, strategies, techniques and models into a complete unity. The type of research used in this research with quantitative descriptive approach, data collection that researchers use is observation, interview, questionnaire and documentation. to master pedagogical competencies there are several that we must know including: (1) Able to know the practicality and potential of learners (2) Able to understand the theory and principles of effective learning (3) Able to design and develop curriculum (4) able to carry out educational learning (5) utilizing learning technology (6) Able to communicate effectively to learners (7) able to evaluate the results of teaching and learning. From the pedagogical competencies above, it is expected that teachers can apply all in Arabic language learning, thus the learners will indirectly be motivated to learn Arabic. With the results of research conducted in pondok Tabfidz. Hidayatul Qur'an Puding Besar class IX there is a linear relationship between students' perception of teacher professionalism reviewved from the competence of pedagogic teachers to the motivation of learning Arabic by $51.4 \%$.
\end{abstract}

\section{Pendahuluan}

Pendidikan adalah sesuatu yang direncanakan, dicapai, diusahakan oleh semua orang agar menjadi manusia yang berpendidikan yang bisa mengembangkan potensi yang mereka miliki. untuk mencapai pendidikan yang baik maka perlu adanya dorongan dan semangat dalam diri seseorang untuk belajar. Adanya semangat dan keinginan untuk belajar siswa akan sunguh-sunguh untuk mencapai tujuan yang mereka ingin capai, dorongan dan semangat tersebut dinamakan motivasi. ${ }^{2}$ Ada beberapa masalah yang sering kita temui didalam pendidikan atau dalam proses pembelajaran siswa kurang semangat dalam belajar itu tidak sepenuhnya kesalahan dari diri siswa tetapi ada factor dari luar yaitu kurangnya motivasi dari orang terdekat baik itu orang tua, teman dan lingkungan sekitarnya. Maka dari itu sebagai pendidik dan orang tua jangan selalu menyalahkan anak yang kurang berprestasi, tetapi kita sebagai pendidik atau orang tua juga harus sadar, apakah kita sudah memberikan yang terbaik untuk siswa atau anak kita. Demngan demikian

\footnotetext{
${ }^{1}$ Nurfuadi, Profesinalisme Guru (Purwokerto: STAIN Press Purwokerto, 2012). Hlm. 18

${ }^{2}$ NOER Rohmah, Psikologi Pendidikan (Yogyakarta: Kalimedia, 2015). Hlm. 176
} 
siswa akan selalau memebutuh motivasi dari orang terdekatnya, dan bagaimana kita memberikan solusi jika terdapat masalah terhadap siswa tersebut.

Ada beberapa masalah yang penlit lihat dan temui disekolah baik dari kompetensi guru maupun persepsi siswa tentang guru, saat pembelajaran yaitu kurangnya persiapan guru sebelum mengajar, karena di awal pembelajaran guru belum menyiapkan RPP hanya berfokus pada buku ajar, menggunakan metode dan strategi yang monoton, kurangnya pengalaman dalam mempraktekkan teknologi yang mendukung dalam pembelajaran dan jarangnya membuat media pembelajaran bahasa Arab, untuk memotivasi siswa dalam belajar bahasa Arab. Kompetensi guru sangat menentukan hasil dan motivasi peserta didik dalam belajar, khusus kompetensi pedagogik yang berhubungan dengan pengetahuan yang pendidik kuasai, karena peserta didik bertanya mengenai bahasa Arab secara luas dan mendetail, dan bagaimana pendidik bisa menjawab pertanyaan tersebut sehingga membuat peserta didik paham mengenai bahasa Arab tersebut. Jika tidak, peserta didik akan berpendapat bahwa pendidik belum siap dalam mengajar, ataupun pendidik belum layak untuk mengajar dalam mata pelajaran tersebut. Selain itu kompetensi pedagogik yang dimiliki seorang pendidik seharusnya selaras atau linear dengan apa yang diajarkannya, supaya ilmuanya bermanfaat, dan apa yang diajarkan sesuai dengan ilmu yang sebenarnya. Kompetensi pedagogik guru juga sangat menentukan hasil akhir atau hasil belajar peserta didik, begitupun pendidik menilai peserta didik melalui kompetensi kognifnya atau pedagogic dari peserta didik. Sebagai pendidik hal mutlak yang harus dimiliki yaitu ada enam komptensi guru yang harus dikuasai, kompetensi yaitu suatu gambaran pengetahuan, keterampilan yang harus dikuasai baik pendidik maupun peserta didik yang harus difikirkan sebelum bertindak. ${ }^{3}$ Masalah pendidikan terjadi dipeserta didik yang sering melenceng tingkah lakunya dari apa yang diajarkan oleh gurunya, sebagai guru harus bisa mengenal perkembangan karakteristik peserta didik agar bisa mencapai pengetahuan sejauh mana peserta didik kuasai. Dengan hal itu berdasarkan undang-undang nomor 14 tahun 20015 dalam pasal 10 ayat 1 mengenai guru dan dosen bahwa kompetensi pedagogic, kompetensi kepribadian, kompetensi social, dan kompetensi profesional merupakan kompetensi yang sanagat penting untuk menciptakan guru yang profesional yang nasional maupun internasional. ${ }^{4}$ Maka dari itu sesuai dengan ketetapan UNESCO bahwa pada tahun 2030, semua Negara yang bergabung dengan perserikatan bangsa-bangsa (PBB) harus memilki kualitas guru yang yang sudah sesuai dengan standar yang telah ditetapkan. ${ }^{5}$ Dalam standar nasional pendidikan, dalam pasal 28 ayat (3) butir c bahwa kompetensi professional adalah kemampuan yang memenuhi standar nasinal pendidikan

\footnotetext{
${ }^{3}$ Ukim Komarudin dan Arief Rahman, Guru (Jakarta: Esensi Erlangga, 2015). Hlm. 2

${ }^{4}$ Asep Jihad dan Suyatno, Menjadi Guru Professional (Jakarta: Elangga, 2013).Hlm.39

5 Undang-Undang Republik Indonesia, “ Nomor 14 Tahun2005 Tentang Guru Dan Dosen, Bab 1 Tentang Ketentuan Umum, Hlm 35," 2005.
} 
yang memiliki penguasaan materi yang mendalam dan luas yang bisa mengajarkan peserta didik menjadi kearah yang lebih baik. Kompetensi professional adalah kompetensi yang semestinya ada dalam diri seorang guru agar proses pembelajaran yang direncanakan sesuai apa yang diharapkan.

Ada yang kita temukan di beberapa sekolah yang mengajarkan bahasa Arab bukan dari guru dalam bidang bahasa Arab itu sendiri, ini salah satu masalah untuk peserta didik. Berlandaskan pada sabda Rasululullah SAW. Dalam sahih Al-Bukhari sebagai berikut :

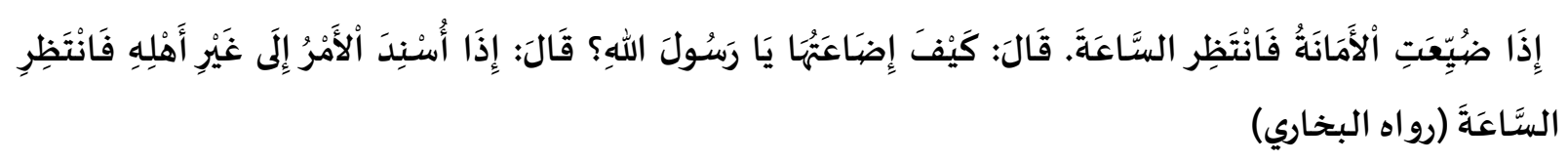

Artinya: Apabila amanah disepelekan, maka tunggulah saat kehancurannya. Sahabat bertanya : apa yang dimaksud menyepelekan amanah? Rasul menjawab: jika urusan diserahkan kepada yang bukan ahlinya, maka tunggulah saat kehancurannya. (HR. Al-Bukhari).

Dengan ayat diatas maka dapat kita simpulkan bahwa untuk menjadi seorang yang memiliki pengetahuan dalam bidang apapun, sebaiknya selaras atau linear dengan apa yang menjadi ahlinya. Menjadi guru, harusnya profesi yang diambil sesuai dengan bidang ahlinya, bukan karena apa yang diinginkannya tetapi tidak memikirkan peserta didik dengan tanggung jawab apa yang telah diajarkannya. Sehingga menjadi guru yang berperan penting adalah kompetensi pedagogik yang dimilikinya.

\section{Metode}

Jenis penelitian yang digunakan dalam penelitian ini adalah deskriptif dengan pendekatan kuantitatif. Metode yang digunakan adalah field research (penelitian lapangan). Sumber data dalam penelitian ini adalah santriwati kelas IX yang merupakan sumber data primer berjumlah 25 orang. Adapun teknik pengumpulan data yang dilakukan oleh peneliti sebagai berikut:

1. Observasi

Obersevasi dilakukan dua kali dengan mengamati secara dalam memasuki dalam proses pembelajaran bahasa Arab didalam kelas IX Pondok Tahfid Hidayatul Qur'an.

2. Wawancara

Wawancara peneliti lakukan 15 menit sebelum mata pelajaran bahasa Arab berakhir dengan bergiliran sehingga tidak mengganggu pembelajaran. Peneliti mewawancarai 7 anak dari kelas tersebut dan memilih secara random dan topic yang ditanyakan mengenai pembelajaran bahasa Arab sehari-hari dikelas.

3. Angket

Angket dengan item butir soal 40, dengan system angket tertutup dengan skala likert 4 .

4. Dokumentasi 
Pengumpulan data yang dilakukan peneliti yaitu mengumpulkan foto kegiatan selama pembelajaran bahasa Arab berlangsung.

\section{Hasil dan Pembahasan}

A. Persepsi

Persepsi merupakan suatu proses penglihatan, pemilihan, perasa untuk mendapatkan informasi hingga bisa menyimpulkan makna. ${ }^{6}$ Terjadinya persepsi dalam otak manusia yaitu ada hubungan dengan lingkungannya, sesuatu yang didengar, dan meliputi semua indera yang aktif yang diberikan Allah terhadap hambaNya. Persepsi siswa ada hubungannya dengan kompetensi guru, disini letak pentingnya setiap tingkah laku guru dinilai oleh peserta didik, kompetensi guru yang dimiliki akan mempengaruhi persepsi peserta didik. Dengan demikian persepsi siswa akan baik jika guru menguasai kompetensi dengan sebenar-benarnya diterapkan dalam mengajar. ${ }^{7}$

Prinsip-prinsip dasar tentang persepsi: a. persepsi itu bukan absolut tetapi relative. b. pendapat yang disimpulkan menjadi informasi yang telah dipilah secara selektif. c. persepsi mempunyai aturan. $d$. persepsi dipengaruhi oleh pengalaman yang terjadi. e. persepsi seseorang dengan sekelompok orang lain akan jauh berbeda walaupun obejek atau situasi yang sama. Jadi persepsi menurut peneliti adalah suatu pandnagan seseorang tentang sesuatu yang mereka lihat dan alami sehingga mendapatkan informasi kedalam otak dan diolah dan mengeluarkan informasi tersebut., itulah yang disebut persepsi.

B. Profesionalisme guru

Profesionalisme adalah sesuatu yang akan diraih, dicapai dan harus dimiliki setiap seorang yang mempunyai profesi masing-masing agar di era pendidikan kita mempunyai orang-orang yang professional dalam bidangnya. Dan peran guru sangat penting dalam era pendidikan yaitu mempunyai guru yang profesionalisme. Professional adalah kegiatan atau pekerjaan yang dilakukan oleh seseorang secara sadar untuk memenuhi kehidupannya yang memerlukan ahli dibidangnya, mempunyai pengalaman dan sudah mempelajari dari aspek kependidikan profesi. ${ }^{8}$ Dalam buku Hamzah B. Uno, menyatakan bahwa kompetensi guru meliputi perencanaan, kemampuan mengajar dikelas, kemampuan untuk melibatkan pembelajaran dengan

\footnotetext{
${ }^{6}$ Slameto, Belajar Dan Factor-Faktor Yang Mempengarubinya (Jakarta: PT . Rineka Cipta, 2015). Hlm. 103

${ }^{7}$ Nuryovi, Ono Wirhana, dan Sriyono, "PERSEPSI SISWA TENTANG KOMPETENSI PEDAGOGIK DAN KOMPETENSI KEPRIBADIAN GURU," Journal of Mechanical Engineering Education Vol. 4, No. 2, (Desember 2017).

${ }^{8}$ Kunandar, Guru Professional Implementasi Kurikulum Tingkat Satuan Pendidikan (KTSP) dan Sukses Dalam Sertifikasi Guru (Jakarta: Raja Grafindo Persada, 2007).
} 
peserta didik yang diajarnya. Kompetensi merupakan sesuatu yang kita miliki dari aspek kognitif, afektif, dan psikomotor menjadi satu kesatuan yang lengkap harus kita imbangi dengan perilaku yang baik dan bisa menjadi contoh untuk peserta didik. Sebagaimana pendapat dari ahli dibidang keguruan ada tiga syarat untuk kita penuhi menjadi professional dibidang keguruan, yaitu satu, memiliki ilmu pengetahuan sesuai dengan bidangnya. Kedua, memiliki keterampilan dibidangnya. Dan ketiga memiliki moral akademik. ${ }^{9} \mathrm{Ada}$ beberapa kompentensi guru, yaitu kompetensi pedagogic, kompetensi social, kompetensi kepribadian, dan kompetensi professional. Disini peneliti akan membahas dari satu kompetensi yaitu kompetensi pedagogik guru.

C. Kompetensi Pedagogik

Pedagogik suatu keterampilan atau kemampuan untuk mendidik menjadi seorang guru suatu keharusan mengusai kompetensi pedagogic, karena dilihat dari segi proses pembelajaran kompetensi pedagogic ini bisa mempermudah guru dalam mengajar jika mempraktekkan kompetensi ini dengan baik dan benar. ${ }^{10}$ Menurut ahli lain menyebutkan pedagogic adalah ilmu yang membicarakan masalah yang terjadi pada peserta didik dan bagaimana mencari solusinya, maka dari itu kompetensi pedagogic adalah kompetensi yang bisa menguasai teori dan prakteknya dalam proses pembelajaran. sebagai guru untuk menguasai kompetensi pedagogic ada beberapa yang harus kita ketahui diantaranya:

1. Mampu mengetahui kerakteristik dan potensi peserta didik

Sebagai guru yang membimbing anak dalam belajar, harusnya sudah menguasai karakteristik peserta didiknya masing-masing, dengan demikian guru dengan mudah mengetahui potensi apa yang dimiliki oleh peserta didik masing-masing, dan sebagai guru bisa mengarahkan peserta didik kebidang apa yang mereka ikuti, dan tugas sebagai guru menjadi pelengkap kekurangan-kekurangan yang belum ada dalam peserta didik tersebut. ${ }^{11}$

2. Mampu memahami teori dan prinsip-prinsip pembelajaran efektif Untuk mencapai pembelajaran yang efektif maka memerlukan partisipasi peserta didik dalam proses pembelajaran, dengan demikian guru sudah mengetahui teoriteori apa yang digunakan ketika sudah berhadapan dengan peserta didik.

3. Mampu merancang dan mengembangkan kurikulum

\footnotetext{
${ }^{9}$ Haidar Putra Daulay, Pendidikan Isalam dan Sistem Pendidikan Nasional Di Indonesia (Jakarta: Kencana Prenada Media Group, 2004). Hlm.196

${ }^{10}$ Muhammad Kristiawan dan Nur Rahmat, "Peningkatan Profesionalisme Guru Melalui Inovasi Pembelajaran," Jurnal Iqra': Kajian Ilmu Pendidikan 3, no. 2 (15 Desember 2018): 373-90, https://doi.org/10.25217/ji.v3i2.348.

${ }^{11}$ Nanang Priatno, dan Tito Sukamto, Pengembangan Profesi Guru (Bandung: PT. Remaja Rosdakarya, 2013) hlm, 38
} 
Profesi guru sudah menjadi keharusan untuk bisa membuat dan menyusun silabus, RPP, modul dan kurikulum. Sehingga guru yang mampu dan bisa mengembangkan hal-hal diatas, seharusnya bisa menyesuaikan kebutuhan pendidikan peserta didik, materi-materi yang diperlukan secara lebih mendalam dan bisa meningkatkan kemampuan peserta didik dengan mudah. ${ }^{12}$

4. Mampu melaksanakan pembelajaran mendidik

Pembelajaran yang mendidik yaitu bukan hanya mendapatkan sebuah hasil belajar yang baik tetapi menguasai ilmu pengetahuan dan teknologi sekaligus menumbuhkan keterampilan soft skills, serta diimbangi dengan sikap yang dan etika teladan menjadi guru professional. ${ }^{13}$

5. Memanfaatkan teknologi pembelajaran ${ }^{14}$

Proses pembelajaran yang baik, serta guru yang professional melakukan pembelajaran secara semaksimal mungkin dengan cara salah satunya dengan teknologi yang mendukung dalam proses pembelajaran, sehingga peserta didik akan antusias mengikuti pembelajaran karena guru tidak hanya menggunakan media atau metode yang monoton

6. Mampu berkomunikasi efektif terhadap peserta didik

Menggunakan komunikasi yang baik dan benar akan memudahkan peserta didik memahami apa yang guru sampaikan, sehingga tidak ada kesalahpahaman dalam menerima pesan, tugas guru mengusai komunikasi yang baik dan benar dan fasih dalam bahasa Arab itu salah satu menentukan hasil belajar peserta didik dengan baik

7. Mampu mengevaluasi hasil belajar-mengajar

Untuk menentukan hasil belajar, capaian dan tujuan pembelajaran, guru harus bisa mengevaluasi baik dari peserta didik maupun guru tersebut. Melakukan evaluasi akan membuat pembelajaran semakin meningkat kedepannya, dengan evaluasi dari mulai proses pembelajaran, tes, dan semua yang mencakupi pembelajaran didalam dan luar kelas. Dan evaluasi akan berguna bagi guru dan peserta didik untuk menyiapkan apa yang kurang selama dari proses pembelajaran sebelumnya. ${ }^{15}$

\footnotetext{
12 Putri Balqis, Nasir Usman, dan Sakdiah Ibrahim, "Kompetensi Pedagogik Guru Dalam Meningkatkan Motivasi Belajar Siswa," Jurnal Administrasi Pendidikan Pascasarjana Universitas Syiah Kuala Vol 2, No 1 (Agustus 2014).

${ }^{13}$ C. Asri Budiningsih, "KARAKTERISTIK SISWA SEBAGAI PIJAKAN DALAM PENELITIAN DAN METODE PEMBELAJARAN,” Jurnal Cakrawala Pendidikan 1, no. 1 (2011), https://doi.org/10.21831/cp.v1i1.4198. ${ }^{14}$ Srianti Srianti, "PERSEPSI SISWA TERHADAP KOMPETENSI PEDAGOGIK GURU SOSIOLOGI DI SMA NEGERI 1 SINJAI SELATAN,” Jurnal Sosialisasi: Jurnal Hasil Pemikiran, Penelitian Dan Pengembangan Keilmuan Sosiologi Pendidikan 2, no. 2 (3 Januari 2017), https://doi.org/10.26858/sosialisasi.v2i2.2556.

${ }^{15}$ Maman Abdurrahman, A. Suherman Masor, dan Asep M. Irfan Fadillah, “Tantangan Guru Bahasa Arab Madrasah Aliyah Dalam Perspektif Kompetensi Pedagogik Dan Profesional.," Jurnal Arabiyat: Jurnal Pendidikan Bahasa Arab dan Kebahasaaraban NO 2 (1) (2015): 43-58.
} 
D. Motivasi Belajar

Motivasi yaitu suatu dorongan, dukungan dan kekuatan kepada sesuatu yang ingin dicapai oleh sesorang baik itu didapatkan dari motivasi internal maupun eksternal. ${ }^{16}$ dengan adanya motivasi peserta didik ada perubahan ke energy yang lebih baik, yaitu ditandai dengan perubahan sikap, perasaan untuk mencapai tujuan besar yang ingin dicapainya. ${ }^{17}$ Sebagai guru kita harus memahami psikology peserta didik agar tidak membuatnya merasa malas, lemah dalam belajar, maka dari itu guru berperan penting dalam memotivasi anak dalam belajar bahasa Arab.

\section{Hasil Penelitian}

Berdasarkan penelitian-penelitian sebelumnya, peneliti membaca permasalaahan yang terjadi dibeberapa penelitian yang telah ditulis, permasalahan yang terjadi tidak jauh berbeda yaitu diantaranya 1). Ditulis oleh Muhammad kristiawati dan Nurrahmat dengan judul peningkatan profesionalisme guru melalui inovasi pembelajaran dengan hasil penelitiannya menyebutkan kajian guru melalui inovasi pembelajaran sangat penting dilaksanakan dalam dunia pendidikan, karena tuntutan sebagai guru di era modern tidak pernah berhenti sehingga selalu membutuhkan inovai-inovasi yang baru. 2. Penelitian yang dilakukan oleh Bakri Anwar dengan judul kompetensi pedagogic sebagai agen pembelajaran, dengan hasil penelitian menyebutkan bahwa pentingnya mengusai kompetensi pedagogic, maka proses pembelajaran akan tercapai secara sempurna. Sedangkan penelitian saya ingin melihat persepsi siswa tentang profesionalime guru ditinjau dari kompetensi pedagogic terhadap motivasi belajar bahasa Arab.

Dari pengamatan peneliti di pondok Tahfidz Hidayatul Qur'an kelas IX C mengenai kompetensi pedagogic guru yaitu pertama dari perencanaan pembelajaran dikelas, guru belum membuat RPP dalam proses pembelajaran, kedua, guru terkesan menggunakan metode yang sama disetiap pertemuan. Ketiga cakupan menggunakan teknologi dalam kompetensi pedagogic guru belum bisa menerapkan dikelas karena sarana yang belum lengkap.

Solusi permasalahan diatas menurut saya semua ada di guru atau pendidik, pandangan ini dilihat dari pendapat dan karya tulis dan ilmuan, ada pendapat dari Ustadz Adi Hidayat dalam ceramahnya menyebutkan bahwa manusia tidak ada yang bodoh, ada peneliti yang melakukan riset tentang IQ otak seorang paling sedikit yaitu seratus juta lebih, jadi bagaimana kita bisa menggunakan IQ kita dengan sebaik mungkin, sebagai

${ }^{16}$ Djamarah Saiful Bahri, Psikologi Belajar (Jakarta: Rineka Cipta, 2011). Hlm. 148 
pendidik harus tahu bagaimana mengajar dengan metode, strategi dan pendekatan yang sesuai kepada peserta didik dengan ilmu yang sebenar-benarnya. Selain itu menurut imam Al-Ghazali sosok guru yang ideal yaitu pertama, kapabilitas personal yaitu guru yang memiliki pengetahuan, ketrampilan yang baik sehingga bisa membuat proses pembelajaran menjadi efektif. Kedua, sebagai innovator, yaitu guru yang sudah memiliki kemampuan kompetensi yang baik bisa memperbaharui proses pembelajaran secara terus menerus hingga bisa mengikuti zaman. Ketiga, guru sebagai developer, yaitu guru harus memiliki visi dan misi dalam dunia pendidikan. ${ }^{18}$

Proses kegiatan belajar megajar yang terjadi secara berualang-ulang akan menimbulkan pengalaman, dengan pengalaman peserta didik dan guru bisa memahami karakteristik masing-masing. Dalam pembelajaran bahasa Arab ada empat keterampilan yang guru harusnya mengusai yaitu kalam, qiro'ah istima' dan kitabah, mengajarkan empat keterampilan ini memang tidak mudah, tugas guru menyampaikan pembelajaran seefektif mungkin dengan menggunakan metode, strategi, pendekatan dan media yang bervarisasi sehingga siswa cepat mengerti dan mengusai pemebelajaran tersebut. Selain ini guru mempunyai peran memberi dorongan, bantuan, support, membimbing, mengawasi dalam yang berkaitan dengan tingkah laku peserta didik yang masih dalam lingkungan sekolah, dan bagaimana jika diluar sekolah mereka masih mentaati norma pertaturan kedisiplinan kepada masyarakat dilingkungannya. Dengan demikian pertumbuhan anak menjadi baik atau tidaknya ada hubungan dengan pendidikan yang diajarkan.

Maka dari itu pendidikan harus bisa menimbulkan motif instrinsik dan ekstrinsik sebaik mungkin, motif instrinsik yaitu menumbuhkan semnagat peserta didik untuk mengembangkan minat yang ada dalam diri peserta didik dan memberikan support atau wadah untuk mengasah kemampuan dalam studiya masing-masing. Misalnya saat mulai pembelajaran guru memberikan tujuan dalam proses akhir mata pelajaran bahasa Arab apa yang harus peserta didik kuasai dan mendapatkan keberhasilan sesuai dengan apa yang diharapkan. Sedangkan untuk menimbulkan motif ekstrinsik ada beberapa yang harus pendidik persiapkan yaitu, a. pendidik harus bisa menimbulkan kesadaran terhadap peserta didik sebagai manusia yang berpribadi, menghargai pendaparnya, sikapnya, perasannyanya. b. pendidik harus bisa melakukan proses pembelajaran dengan berbagai metode. c. pendidik harus bisa mengayomi jika peserta didik mengalami kesulitan dalam akademik, tidak memandang pribadi dari peserta didik. d. pendidik mengusai dan mempunyai pengalaman dan pengetahuan luas dalam bidang yang diajarkan. e. dan

\footnotetext{
${ }^{18}$ Abu Muhammad Iqbal, Pemikiran Pedidikan Islam Gagasan-Gagasan Besar Para Ilmuwan Muslim. (Yogyakarta: Pustaka Belajar, 2015).hlm. 96
} 
pendidik menikmati profesinya sebagai pendidik. ${ }^{19}$ Sebagai pendidik jadilalah pendidik yang cerdas, baik akhlaknya, dan sempurna akalnya.

\section{Hasil analisis wawancara yang peneliti lakukan terhadap siswa kelas III C}

Analisis mengenai evaluasi yang guru gunakan dalam pembelajaran bahasa Arab yaitu tes menggunakan essay, atau pertanyaan langsung dan menjelaskan tujuan sebelum pembeljaran berlangsung. Guru mampu untuk menyampaiakn materi terkait bahasa Arab yang berpedoman dengan buku ajar dan bersemangat dalam mengajar sehingga murid mudah memahami materi. Untuk media ajar lainnya guru belum menggunakan selain papan tulis, spidol dan buku. Secara keseluruhan siswa mudah memahami pembelajaran bahasa Arab dan termotivasi untuk memehami bahasa Arab secara lebih mendalam.

Berdasarkan hasil wawancara diatas, peneliti menyimpulkan bahwa, motivasi yang didapatkan oleh siswa dalam belajar bahasa Arab pada saat mereka melihat para ustadz dan ustadzah fasih berbicara bahasa Arab, dan ada seseorang siswa yang orang tuanya dengan mengusai bahasa Arab maka pekerjaan selalu menghampiri mereka. Selain itu guru didalam kelas saat mengajar menggunakan bahasa Arab yang bagus secara tidak langsung mereka termotivasi untuk bisa bahasa Arab. Sebagai guru harus bisa menerapkan antara pengetahuan pedagogik dengan pengetahuan teknologi, peneliti mewawancarai murid guru jarang menggunakan teknologi dalam pembelajaran, menurut peneliti ini dikarenakan kurang lengkapnya sarana untuk pembelajaran. Tetapi guru bisa menggunakan media lainnya untuk mensukseskan pembelajaran bahasa Arab. Untuk bermain game pada saat pembelajaran bahasa Arab jarang dilakukan, guru sering membuat pertanyaan langsung kepada peserta didik secara bergiliran.

\section{Hasil laporan observasi di kelas III C Pondok Tahfidz Hidayatul Qur'an}

Analisis hasil observasi yaitu pengelolaan dalam pembelajaran, pembelajaran dimulai dan berlangsung dengan efektif, kurikulum yang digunakan yaitu K-13, saat mengajar guru belum menyiapkan RPP. Untuk metode guru menggunakan metode ceramah dan kemudian menanyakan langsung kepada peserta didik apakah ada pertanyaan atau materi yang belum dipahami, guru sangat memperhatikan peserta didik, dan sangat mengutamakan apa yang diinginkan peserta didik agar pemebelajaran berlangsung secara nyaman dan semangat. Salah satu membuat peserta didik termotivasi dalam bahasa Arab yaitu untuk memotivasi siswa guru harus menggunakan bahasa Arab disaat pembelajaran, dan guru memuji siswa jika melakukan hal yang benar dan mengecek pekerjaan siswa satu persatu. Guru mengevaluasi pembelajaran dengan memberikan tugas setelah pemberian materi dan menyuruh siswa untuk maju kedepan kelas menulis

\footnotetext{
${ }^{19}$ Hamzah B. Uno dan Nina Lamatenggo, Tugas Guru dalam Pembelajaran (Jakarta: Bumi Aksara, 2016).Hlm. 4
} 
jawabannya, dan juga menulis di buku tugas, setelah itu guru memeriksa jawaban siswa masing-masing. Menurut pengamatan peneliti guru bisa menjadi teladan untuk peserta didiknya baik itu dari segi kompetensi pedagogik maupun kompetensi kepribadiannya. Karena saat didaalm pembelajarannya guru menggunakan bahasa Arab dengan fasih. Dan peserta diluar kelas sangat memperhatikan sopan dan satun.

\section{Hasil Uji Linearitas}

ANOVA Table

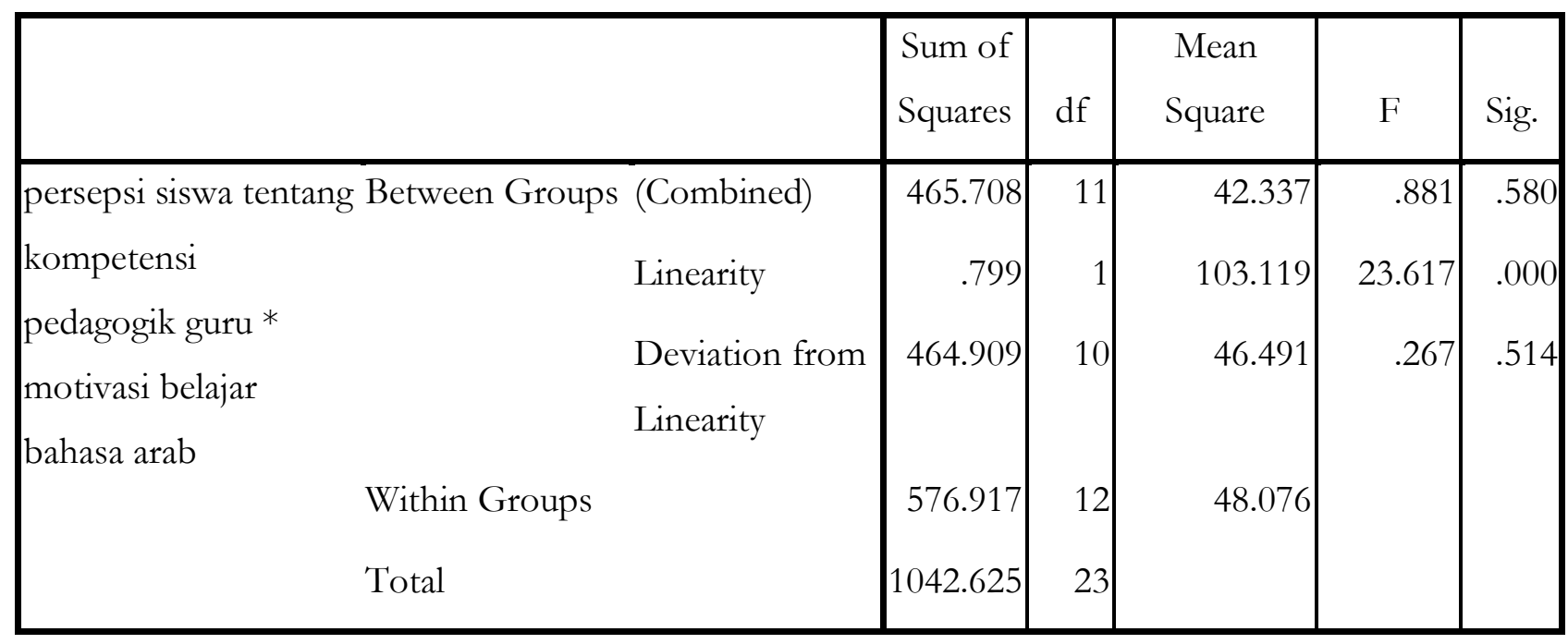

Berdasarkan hasil uji linearitas diatas maka dapat kita ketahui nilai sig devition from linearity 0,514 >0,005 maka dapat kita simpulkan bahwa ada terdapat hubungan yang linear antara persepsi siswa tentang profesionalime guru ditinjau dari kompetensi pedagodik guru terhadap motivasi belajar bahasa Arab sebesar $51,4 \%$.

Tabel 1.3

Validity Statistics

Hasil Uji Validitas Persepsi Siswa Tentang Profesionalisme Guru Ditinjau Dari Kompetensi Pedagogic Terhadap Motivasi Belajar Bahasa Arab

\begin{tabular}{cccc}
\hline Butir Soal & R Hitung & R Table 5\% (23) & Kriteria \\
\hline 1 & .470 & 0,3961 & Valid \\
\hline 2 & 557 & 0,3961 & Valid \\
\hline 3 & 489 & 0,3961 & Valid \\
\hline 4 & .444 & 0,3961 & Tidalid \\
\hline 5 & .174 & 0,3961 & Valid \\
\hline 6 & .531 & 0,3961 & Valid \\
\hline 7 & .751 & 0,3961 &
\end{tabular}




\begin{tabular}{|c|c|c|c|}
\hline 8 & .741 & 0,3961 & Valid \\
\hline 9 & .446 & 0,3961 & Valid \\
\hline 10 & .635 & 0,3961 & Valid \\
\hline 11 & 173 & 0,3961 & Tidak valid \\
\hline 12 & .284 & 0,3961 & Tidak valid \\
\hline 13 & $.534 * *$ & 0,3961 & Valid \\
\hline 14 & .483 & 0,3961 & Valid \\
\hline 15 & .437 & 0,3961 & Valid \\
\hline 16 & .506 & 0,3961 & Valid \\
\hline 17 & .195 & 0,3961 & Tidak valid \\
\hline 18 & .139 & 0,3961 & Tidak valid \\
\hline 19 & $.577 * *$ & 0,3961 & Valid \\
\hline 20 & .463 & 0,3961 & Valid \\
\hline 21 & $.664 * *$ & 0,3961 & Valid \\
\hline 22 & .263 & 0,3961 & Tidak valid \\
\hline 23 & $.455^{*}$ & 0,3961 & Valid \\
\hline 24 & $.742^{* *}$ & 0,3961 & Valid \\
\hline 25 & $.588^{* *}$. & 0,3961 & Valid \\
\hline 26 & .397 & 0,3961 & Valid \\
\hline 27 & $.778^{* *}$ & 0,3961 & Valid \\
\hline 28 & .571 & 0,3961 & Valid \\
\hline 29 & .421 & 0,3961 & Valid \\
\hline 30 & .501 & 0,3961 & Valid \\
\hline 31 & $.656^{* *}$ & 0,3961 & Valid \\
\hline 32 & .325 & 0,3961 & Tidak valid \\
\hline 33 & .435 & 0,3961 & Valid \\
\hline 34 & .430 & 0,3961 & Valid \\
\hline 35 & .486 & 0,3961 & Valid \\
\hline 36 & .528 & 0,3961 & Valid \\
\hline 37 & .151 & 0,3961 & Tidak valid \\
\hline 38 & .764 & 0,3961 & Valid \\
\hline 39 & $.526^{* *}$ & 0,3961 & Valid \\
\hline 40 & $.529 * *$ & 0,3961 & Valid \\
\hline
\end{tabular}

Dasar pengambilan keputusan validitas

1. jika nilai $r$ hitung $>\mathrm{r}$ table maka butir soal angket dinyatakan valid

2. jika nilai $\mathrm{r}$ hitung $<\mathrm{r}$ tabel maka butir soal angket dinyatakan tidak valid ${ }^{20}$

Berdasarkan hasil tabel diatas bahwa dapat kita simpulkan ada 8 item karena nilainya dibawah dari nilai $\mathrm{r}$ tabel yaitu 0,3961. Sementara $\mathrm{r}$ hitung yang valid itu memiliki hubungan yang valid antara item-item yang lain.

${ }^{20}$ V. Wiratna Sujarweni, Metode Penelitian: Lengkap, Praktis Dan Mudah Dipahami (Yohyakarta: Pustaka Baru Press, 2014). Hlm.192 
Tabel 1.4

Reliability Statistics

\begin{tabular}{cc}
\hline Cronbach's Alpha & N of Items \\
\hline .721 & 32 \\
\hline
\end{tabular}

Dari tabel diatas mendapatkan nilai cronbach apha sebesar 72,1\% maka dapat kita simpulkan bahwa cronbach alpha $>0,60$ maka tingkat reabilitas dinyatakan baik. ${ }^{21}$

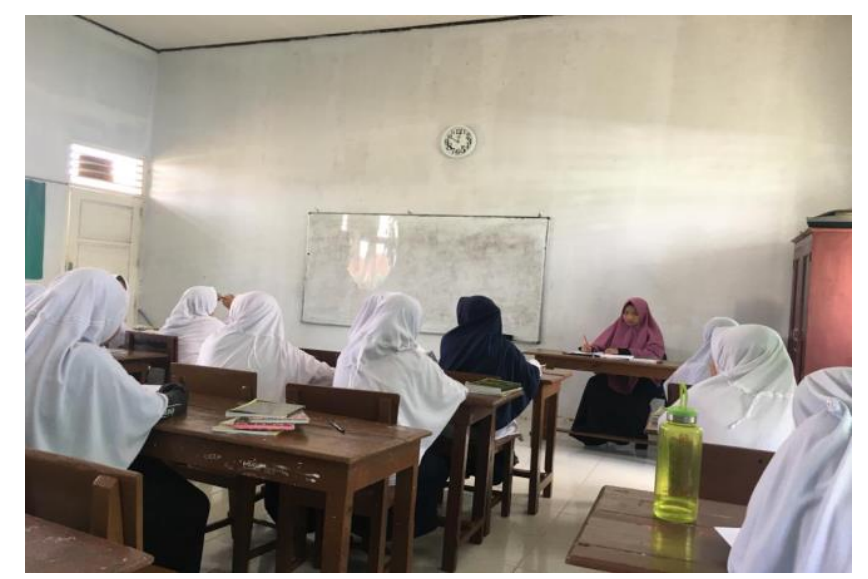

Gambar 1. Proses kegiatan belajar mengajar di Pondok Tahfidz Hidayatul Qur'an

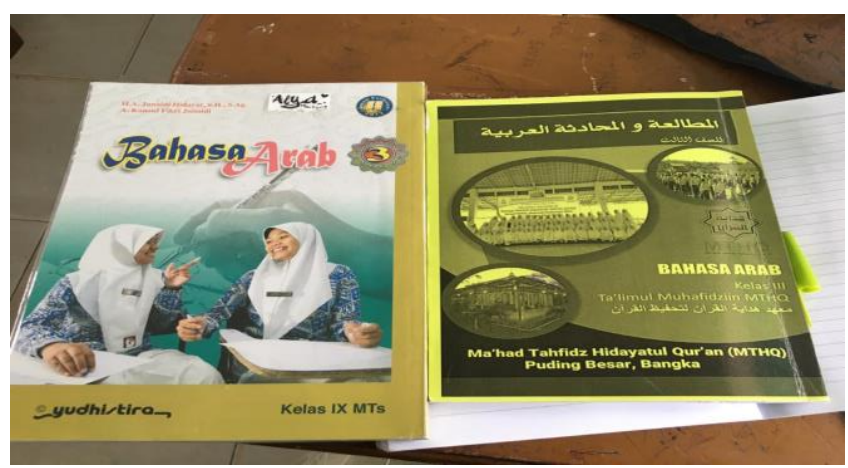

Gambar 2. Buku ajar Bahasa Arab

\section{Kesimpulan}

Simpulan pengamatan peneliti sendiri dan berdasarkan yang terjadi didalam kelas saat proses pembelajaran berlangsung mengenai profesionalisme guru ditinjau dari kompetensi pedagogik guru yaitu: pertama dari perencanaan pembelajaran dikelas, guru belum membuat RPP dalam proses pembelajaran, kedua, guru terkesan menggunakan metode yang sama disetiap pertemuan. Ketiga cakupan menggunakan teknologi dalam kompetensi pedagogic guru belum bisa menerapkan dikelas karena sarana yang belum lengkap. Selain itu menurut imam Al-Ghazali

${ }^{21}$ Pallant J, SPSS Survival Manual: A Step By Step Guide To Data Analysis Using The SPSS Programe (New York: McGraw Hill, 2010). 
sosok guru professional yaitu pertama, kapabilitas personal yaitu guru yang memiliki pengetahuan, ketrampilan yang baik sehingga bisa membuat proses pembelajaran menjadi efektif. Kedua, sebagai innovator, yaitu guru yang sudah memiliki kemampuan kompetensi yang baik bisa memperbaharui proses pembelajaran secara terus menerus hingga bisa mengikuti zaman. Ketiga, guru sebagai developer, yaitu guru harus memiliki visi dan misi dalam dunia pendidikan. Ada mahfudzot yang berbunyi "Guru juga harus mengetahui materi itu tidak penting tanpa adanya metode, dan metode pun juga tidak penting tanpa adanya guru, dan lebih lagi guru itu tidak penting jika tidak ada ruh/jiwa guru didalamnya."

\section{Daftar Pustaka}

Abdurrahman, Maman, A. Suherman Masor, dan Asep M. Irfan Fadillah. “Tantangan Guru Bahasa Arab Madrasah Aliyah Dalam Perspektif Kompetensi Pedagogik Dan Profesional." Jurnal Arabiyat: Jurnal Pendidikan Bahasa Arab dan Kebahasaaraban NO 2 (1) (2015): 43-58.

B. Uno, Hamzah, dan Nina Lamatenggo. Tugas Guru dalam Pembelajaran. Jakarta: Bumi Aksara, 2016.

Balqis, Putri, Nasir Usman, dan Sakdiah Ibrahim. "Kompetensi Pedagogik Guru Dalam Meningkatkan Motivasi Belajar Siswa." Jurnal Administrasi Pendidikan Pascasarjana Universitas Syiah Kuala Vol 2, No 1 (Agustus 2014).

Budiningsih, C. Asri. "KARAKTERISTIK SISWA SEBAGAI PIJAKAN DALAM PENELITIAN DAN METODE PEMBELAJARAN." Jurnal Cakrawala Pendidikan 1, no. 1 (2011). https://doi.org/10.21831/cp.v1i1.4198.

J, Pallant. SPSS Survival Manual: A Step By Step Guide To Data Analysis Using The SPSS Programe. New York: McGraw Hill, 2010.

Jihad, Asep dan Suyatno. Menjadi Guru Professional. Jakarta: Elangga, 2013.

Komarudin, Ukim, dan Arief Rahman. Guru. Jakarta: Esensi Erlangga, 2015.

Kristiawan, Muhammad, dan Nur Rahmat. "Peningkatan Profesionalisme Guru Melalui Inovasi Pembelajaran.” Jurnal Iqra' : Kajian Ilmu Pendidikan 3, no. 2 (15 Desember 2018): 373-90. https://doi.org/10.25217/ji.v3i2.348.

Kunandar. Guru Professional Implementasi Kurikulum Tingkat Satuan Pendidikan (KTSP) dan Sukses Dalam Sertifikasi Guru. Jakarta: Raja Grafindo Persada, 2007.

Muhammad Iqbal, Abu. Pemikiran Pedidikan Islam Gagasan -Gagasan Besar Para Ilmunan Muslim. Yogyakarta: Pustaka Belajar, 2015.

Nurfuadi. Profesinalisme Guru. Purwokerto: STAIN Press Purwokerto, 2012.

Nuryovi, Ono Wirhana, dan Sriyono. "PERSEPSI SISWA TENTANG KOMPETENSI PEDAGOGIK DAN KOMPETENSI KEPRIBADIAN GURU.” Journal of Mechanical Engineering Education Vol. 4, No. 2, (desember 2017).

Putra Daulay, Haidar. Pendidikan Isalam dan Sistem Pendidikan Nasional Di Indonesia. Jakarta: Kencana Prenada Media Group, 2004.

Rohmah, NOER. Psikologi Pendidikan. Yogyakarta: Kalimedia, 2015.

Saiful Bahri, Djamarah. Psikologi Belajar. Jakarta: Rineka Cipta, 2011.

Slameto. Belajar Dan Factor-Faktor Yang Mempengarubinya. Jakarta: PT . Rineka Cipta, 2015.

Srianti, Srianti. "PERSEPSI SISWA TERHADAP KOMPETENSI PEDAGOGIK GURU SOSIOLOGI DI SMA NEGERI 1 SINJAI SELATAN." Jurnal Sosialisasi: Jurnal Hasil Pemikiran, Penelitian Dan Pengembangan Keilmuan Sosiologi Pendidikan 2, no. 2 (3 Januari 2017). https://doi.org/10.26858/sosialisasi.v2i2.2556. 
128 | Volume 11, Nomor 2, Desember 2020

Sujarweni, V. Wiratna. Metode Penelitian: Lengkap, Praktis Dan Mudah Dipahami. Yohyakarta: Pustaka Baru Press, 2014.

Undang-Undang Republik Indonesia. "Undang-Undang Republik Indonesia Nomor 14

Tahun2005 Tentang Guru Dan Dosen, Bab 1 Tetang Ketentuan Umum, Hlm 35,” 2005. 